\title{
A NEW LINDQVIST-TYPE HEXAMOLYBDATE CLUSTER FUNCTIONALIZED WITH THE $\pi$-DONOR LIGAND 4-BROMO-2,6-DIMETHYLPHENYLIMIDO. SPECTROSCOPIC, ELECTROCHEMICAL AND STRUCTURAL STUDIES
}

\author{
MARCELA CORTÉS ${ }^{a}$, MAURICIO FUENTEALBA ${ }^{b}$, CAROLINA MANZUR ${ }^{a}$, DAVID CARRILLO ${ }^{a}{ }^{*}$ \\ ${ }^{a}$ Laboratorio de Química Inorgánica, Instituto de Química, \\ Pontificia Universidad Católica de Valparaiso, Avenida Brasil 2950, Valparaíso, Chile \\ ${ }^{b}$ Laboratorio de Cristalografia, Departamento de Física, Universidad de Chile, Blanco Encalada 2008, Santiago, Chile
}

\begin{abstract}
A new ionic organic-inorganic hybrid complex of formula $\left(n-\mathrm{Bu}_{4} \mathrm{~N}\right)_{2}\left[\mathrm{Mo}_{6} \mathrm{O}_{18}(\mathrm{NR})\right] \cdot 1 / 2 \mathrm{Me}_{2} \mathrm{CO}, \mathrm{R}=-\mathrm{C}_{6} \mathrm{H}_{2}-2,6-\mathrm{Me}_{2}-4-\mathrm{Br}_{2},\left(n-\mathrm{Bu}_{4} \mathrm{~N}\right)_{2}[\mathbf{1}] \cdot \frac{1}{2} \mathrm{Me}{ }_{2} \mathrm{CO}, \mathrm{has}$ been prepared in acetonitrile by reacting tetrabutylammonium $\alpha$-octamolybdate, $\left(n-\mathrm{Bu}_{4} \mathrm{~N}\right)_{4}\left[\alpha-\mathrm{Mo}_{8} \mathrm{O}_{26}\right]$, with 2,6-dimethyl-4-bromoaniline hydrochloride, $2,6-\mathrm{Me}_{2}-$ 4- $\mathrm{Br}_{-} \mathrm{C}_{6} \mathrm{H}_{2} \mathrm{NH}_{2} \cdot \mathrm{HCl}$, using N,N'-dicyclohexylcarbodiimide, $\left(\mathrm{C}_{6} \mathrm{H}_{11}\right) \mathrm{N}=\mathrm{C}=\mathrm{N}\left(\mathrm{C}_{6} \mathrm{H}_{11}\right)$, as dehydrating agent. This complex, formulated as $\left(n-\mathrm{Bu}_{4} \mathrm{~N}\right)_{2}[1] \cdot 1 / 2 \mathrm{Me}_{2} \mathrm{CO}$, contains a C-Br group which can be functionalized for constructing novel hybrid materials. The complex was fully characterized by IR, UV-Vis, ${ }^{4} \mathrm{H}-$ and ${ }^{13} \mathrm{C}-\mathrm{NMR}$ spectroscopies, and authenticated by single crystal X-ray diffraction analysis. The asymmetric unit contains two crystallographically independent anions, $[\mathbf{1}]^{2-}$, differing by the orientation of the phenyl ring relative to the hexamolybdate skeleton, and one molecule of acetone. Both molecules differ in the angles Mo(1)$\mathrm{N}(1)-\mathrm{C}(1)=172.2(6)$ and $\mathrm{Mo}(7)-\mathrm{N}(2)-\mathrm{C}(9)=175.6(6)^{\circ}$. These angles, near to $180^{\circ}$, indicate the presence of a Mo $\equiv \mathrm{N}$ triple bond.
\end{abstract}

Keywords: areneimido-derivative, phenylimido-derivative, Lindqvist-type hexamolybdate, polyoxometalate, crystal structure, conformational isomers.

\section{INTRODUCTION}

Since the pioneering paper of Maatta $\mathrm{et} \mathrm{al.}{ }^{1}$ describing the synthesis and Xray structural determination of the first Lindqvist-type organoimido-derivative of hexamolybdate formulated as $\left[\mathrm{Mo}_{6} \mathrm{O}_{18}\left(\mathrm{NC}_{6} \mathrm{H}_{4} \mathrm{Me}-p\right)\right]^{2-}$, a number of new organoimido-derivatives of hexamolybdate,,$^{2-19}$ hexatungstate,,$^{20}$ and pentatu ngstenmolybdate, ${ }^{21}$ have been synthesized, spectroscopically characterized and, the majority, structurally authenticated by X-ray diffraction analysis. Very recently, the stability, bonding character, electronic properties, first hyperpolarizabilities of this type of complexes have also been studied by Density Functional Theory (DFT)..$^{22-24}$ Likewise, several topics concerning the progresses in polyoxometalate chemistry have been published ${ }^{25 a}$ and, particularly, that dealing with derivatized polyoxometalates including organic and organometallic entities. ${ }^{25 b}$ Among these complexes, the chloro- ${ }^{12}$, bromo- ${ }^{12,18}$ and iodoareneimido hexamolybdates ${ }^{7-10,13-15}$ and iodoareneimido pentatungstenmolybdate ${ }^{21}$ seems to be of great importance considering their potential applications as precursors for the synthesis of new organicinorganic hybrids containing additional organic $\mathrm{c}^{7,8,10,14,15}$ or organometallic ${ }^{13}$ groups, or two similar clusters linked by an extended $\pi$-conjugated organic spacer. ${ }^{8-10,15}$ These halogenated precursors have successfully been applied for the synthesis of organoimido-hexamolybdates as polymer pendants ${ }^{5}$ and main-chain polymers. ${ }^{9,15}$ In this paper we report the synthesis, spectroscopic characterization, electrochemical studies and the X-ray crystal and molecular structure of the new organic-inorganic hybrid bearing the electron-withdrawal bromo group in a remote position: $\left(n-\mathrm{Bu}_{4} \mathrm{~N}\right)_{2}\left[\mathrm{Mo}_{6} \mathrm{O}_{18}\left(\mathrm{NC}_{6} \mathrm{H}_{2}-2,6-\mathrm{Me}_{2}-4-\right.\right.$ $\mathrm{Br})]^{1 / 1} / 2 \mathrm{Me}_{2} \mathrm{CO},\left(n-\mathrm{Bu}_{4} \mathrm{~N}\right)_{2}[1] \cdot 1 / 2 \mathrm{Me}_{2} \mathrm{CO}$. The X-ray structure of a similar hybrid compound of formula $\left(n-\mathrm{Bu}_{4} \mathrm{~N}\right)_{2}\left[\mathrm{Mo}_{6} \mathrm{O}_{18}\left(\mathrm{NC}_{6} \mathrm{H}_{4}-4-\mathrm{Br}\right)\right]$, has previously been described in the literature ${ }^{18}$.

\section{EXPERIMENTAL SECTION}

\section{General remarks}

Solvents were dried and distilled under dinitrogen by standard methods prior to use. Reagents were purchased from commercial suppliers and used without further purification. $\left(n-\mathrm{Bu}_{4} \mathrm{~N}\right)_{4}\left[\alpha-\mathrm{Mo}_{8} \mathrm{O}_{26}\right]$ was synthesized according to published procedures. ${ }^{26}$ Microanalytical data were obtained on a Perkin Elmer model 2400 elemental analyzer. IR spectra were obtained as $\mathrm{KBr}$ disks on a Perkin Elmer model 1600 FT-IR spectrophotometer, in the range of 4000$450 \mathrm{~cm}^{-1}$. Electronic spectra were recorded in $\mathrm{MeCN}$ and DMSO solutions with a Spectronic, Genesys 2, spectrophotometer. ${ }^{1} \mathrm{H}$ - and ${ }^{13} \mathrm{C}-\mathrm{NMR}$ spectra were acquired at $297 \mathrm{~K}$ on a multinuclear Bruker AC 400 spectrometer in acetone$d_{6}$. All NMR spectra are reported in ppm $(\delta)$ relative to tetramethylsilane, with the residual solvent proton resonances and carbon resonances used as internal standards. Coupling constants $(J)$ are reported in Hertz $(\mathrm{Hz})$, and integrations are reported as number of protons. The following abbreviations are used to describe peak patterns: $\mathrm{br}=$ broad, $\mathrm{s}=$ singlet, $\mathrm{d}=$ doublet, $\mathrm{t}=$ triplet, $\mathrm{m}=$ =multiplet. Electrochemical measurements were performed using a Radiometer Analytical model PGZ 100 all-in-one potentiostat, using a standard three-electrode setup with a platinum electrode, platinum wire auxiliary electrode and $\mathrm{Ag} / \mathrm{AgCl}$ as the reference electrode. DMF solutions were $1.0 \mathrm{mM}$ in the compound under study and $0.1 \mathrm{M}$ in the supporting electrolyte $n-\mathrm{Bu}_{4} \mathrm{~N}^{+} \mathrm{PF}_{6}^{-}$with the voltage scan rate $=100 \mathrm{mV} \mathrm{s}^{-1}$. Melting point was determined in evacuated capillary and was not corrected.

\section{Synthesis of $\left(\mathrm{n}-\mathrm{Bu}_{4} \mathrm{~N}\right)_{2}[1] \cdot 1 / 2 \mathrm{Me}_{2} \mathrm{CO}$}

A mixture of $6.45^{4} \mathrm{~g}(3.0 \mathrm{mmol})$ of $\left(n-\mathrm{Bu}_{4} \mathrm{~N}\right)_{4}\left[\alpha-\mathrm{Mo}_{8} \mathrm{O}_{26}\right], 1.42 \mathrm{~g}(6.0$ $\mathrm{mmol}$ ) of 2,6-dimethyl-4-bromoaniline hydrochloride, $2,6-\mathrm{Me}_{2}-4-\mathrm{Br}$ $\mathrm{C}_{6} \mathrm{H}_{2} \mathrm{NH}_{2} \cdot \mathrm{HCl}$, and $2.11 \mathrm{~g}(10.2 \mathrm{mmol})$ of N,N'-dicyclohexylcarbodiimide, $\left(\mathrm{C}_{6} \mathrm{H}_{11}\right) \mathrm{N}=\mathrm{C}=\mathrm{N}\left(\mathrm{C}_{6} \mathrm{H}_{11}\right)^{7}$, were dissolved in $50 \mathrm{~mL}$ of acetonitrile and refluxed for $12 \mathrm{~h}$ under $\mathrm{N}_{2}$. Then, the reaction mixture was allowed to stand at room temperature. The white solid, corresponding to the dicyclohexylurea, was filtered off. The filtrate was concentrated under vacuum and the red colloidal residue was dissolved in acetone and then layered with ethanol and allow to stand at $-18^{\circ} \mathrm{C}$. A red crystalline solid was deposited, which was filtered off, washed with diethyl ether, and dried under vacuum. Suitable single crystals were chosen of this crop for an X-ray diffraction structure determination. Yield $3.34 \mathrm{~g}\left(72 \%\right.$ based on Mo), m. p. $236^{\circ} \mathrm{C}$. Anal. Calcd $\mathrm{C}_{83} \mathrm{H}_{166} \mathrm{Br}_{2} \mathrm{Mo}_{12} \mathrm{~N}_{6} \mathrm{O}_{37}$, $\mathrm{Mr}=3151.32 \mathrm{gmol}^{-1}$ : calcd C, 31.63; H, 5.31; N, 2.67. Found C, 31.54; H, 5.26; $\mathrm{N}, 2.54$. UV/Vis $(\mathrm{Me}-\bar{\nu}): \lambda_{\max }\left(\log \varepsilon / \mathrm{Lmol}^{-1} \mathrm{~cm}^{-1}\right)=254$ (4.56), 274sh (4.47), 358 (4.37). IR (KBr): $\boldsymbol{V}=2961 \mathrm{~s}, 2920 \mathrm{~m}, 2874 \mathrm{~m}(\mathrm{C}-\mathrm{H}) ; 975 \mathrm{~m}(\mathrm{Mo}-\mathrm{N}) ; 950 \mathrm{vs}$ $\left(\mathrm{Mo}-\mathrm{O}_{\mathrm{t}}\right)$; 790vs (Mo-O-Mo) cm-1. ${ }^{1} \mathrm{H}$ NMR $\left(400 \mathrm{MHz}, \mathrm{CD}_{3} \mathrm{COCD}_{3}\right): \delta=0.97$ $\left(\mathrm{t}, \mathrm{CH}_{3}, 24 \mathrm{H}\right) ; 1.44\left(\mathrm{~m}, \mathrm{CH}_{2}, 16 \mathrm{H}\right) ; 1.80\left(\mathrm{~m}, \mathrm{CH}_{2}, 16 \mathrm{H}\right) ; 2.17\left(\mathrm{~s}, \mathrm{CH}_{3}, 6 \mathrm{H}\right) ; 3.43$ $\left(\mathrm{t}, \mathrm{N}-\mathrm{C} H_{2}, 16 \mathrm{H}\right) ; 7.23(\mathrm{~s}, \mathrm{Ar} H, 2 \mathrm{H}) .{ }^{13} \mathrm{C}$ NMR $\left(400 \mathrm{MHz}, \mathrm{CD}_{3} \mathrm{COCD}_{3}\right): \delta=$ $13.92\left(\mathrm{CH}_{3}\right) ; 18.38\left(\mathrm{CH}_{2}\right) ; 20.38\left(\mathrm{CH}_{2}\right) ; 24.52\left(\mathrm{Me}_{2}-2,6\right) ; 59.36\left(\mathrm{CH}_{2}\right) ; 120.56$ $(C-4) ; 130.39(C-3) ; 140.34(C-2) ; 153.18\left(C_{i p s o}\right)$.

\section{Structure determination of $\left(\mathrm{n}-\mathrm{Bu}_{4} \mathrm{~N}\right)_{2}[1] \cdot \frac{1}{2} \mathrm{Me}_{2} \mathrm{CO}$}

Complete details of the crystal, X-ray data collection, and structure solution are provided as Supporting Information. Semi-empirical corrections, via $\psi$-scans, were applied for absorption. Intensity data were collected on a Bruker Smart Apex diffractometer equipped with a bidimensional CCD detector using graphite monochromated Mo-K $\alpha$ radiation $(\lambda=0.71073 \AA)$. The diffraction frames were integrated using the SAINT package ${ }^{27}$, and corrected for absorption with $\mathrm{SADABS}^{28}$. The structure was solved using XS in SHELXTL-PC ${ }^{29}$ by direct methods and completed (non-H atoms) by difference Fourier techniques. Refinement was performed by the full-matrix least-squares method based on $F^{2}$. Anisotropic thermal parameters were refined for all non-hydrogen atoms. Hydrogen atoms were placed in their calculated positions, assigned fixed isotropic thermal parameters and allowed to ride on their respective parent atoms.

\section{RESULT AND DISCUSSION}

Synthesis and spectroscopic characterization

It is well known that the synthesis of organoimido-derivatives of polyoxometalates in reasonable yield using anilines containing an electron- 
withdrawing group in the phenyl ring is very difficult. The presence of this type of group, $v$. gr., chloro or bromo, provokes a deactivation of the amine group and, consequently, a diminution of its nucleophilic ability. Fortunately, Peng et al. have discovered that the addition of the dehydrating agent dicyclohexylcarbodiimide (DCC), facilitates the reaction of hexamolybdate with anilines, giving very good yields. ${ }^{7}$ Recently, this group has described two new organoimido-derivatives of hexamolybdate using 2-, 3- and 4-chloro- ${ }^{12}$ and 4-bromoanilines. ${ }^{12,18}$ The reaction of 2,6- $\mathrm{Me}_{2}-4-\mathrm{Br}$-aniline as hydrochloride with tetra-butylammonium $\alpha$-octamolybdate, $\left(n-\mathrm{Bu}_{4} \mathrm{~N}\right)_{4}\left[\alpha-\mathrm{Mo}_{8} \mathrm{O}_{26}\right]$, and DCC in refluxing acetonitrile, has effectively allowed the synthesis of $(n-$ $\left.\mathrm{Bu}_{4} \mathrm{~N}\right)_{2}[1] \cdot 1 / 2 \mathrm{Me}_{2} \mathrm{CO}$ in $72 \%$ yield. The role of the proton in the enhancement of the electrophilic ability of DCC toward the terminal oxo atom of the $\mathrm{Mo}=\mathrm{O}$ group and in the conversion of the $\left[\alpha-\mathrm{Mo}_{8} \mathrm{O}_{26}\right]^{4-}$ into $\left[\mathrm{Mo}_{6} \mathrm{O}_{19}\right]^{2-}$ through a degradation and re-assembly process, has recently been discussed. ${ }^{9,18}$

Complex $\left(n-\mathrm{Bu}_{4} \mathrm{~N}\right)_{2}[1] \cdot 1 / 2 \mathrm{Me}_{2} \mathrm{CO}$ was obtained as red and air stable crystalline solid, and was fully characterized by ${ }^{1} \mathrm{H}-$ and ${ }^{13} \mathrm{C}-\mathrm{NMR}$, IR and UVvis spectroscopy (see Experimental Section). The crystalline and molecular structure of this complex was determined by single crystal X-ray diffraction analysis (vide infra). The more salient features of the ${ }^{1} \mathrm{H}-\mathrm{NMR}$ spectrum of this compound are (i) the singlet resonance in the at $2.17 \mathrm{ppm}$ corresponding to the proton resonances of the methyl groups occupying the symmetrical 2,6-positions and the singlet at $7.23 \mathrm{ppm}$ corresponding to the resonances of protons placed in the symmetrical 3,5-positions of the phenyl ring and (ii) the four groups of signals corresponding to the proton resonances of the two $n-\mathrm{Bu}_{4} \mathrm{~N}^{+}$cations. Likewise, consistent with the proposed structure, the proton-decoupled ${ }^{13} \mathrm{C}$-NMR spectrum of complex $\left(n-\mathrm{Bu}_{4} \mathrm{~N}\right)_{2}[1] \cdot \frac{1}{2} \mathrm{Me}_{2} \mathrm{CO}$ exhibits the expected characteristic sharp resonances of the phenyl ring carbon atoms and the resonances of the methyl carbon atoms placed in the 2,6-positions (see Experimental Section). On the other hand, the IR spectrum of $\left(n-\mathrm{Bu}_{4} \mathrm{~N}\right)_{2}[1] \cdot 1 / 2 \mathrm{Me}_{2} \mathrm{CO}$ is characterized by the very strong absorption bands at 950 and $790 \mathrm{~cm}^{-1}$ attributed to the $\mathrm{Mo}=\mathrm{O}$ and Mo-O-Mo stretching modes, ${ }^{11,13,19}$ respectively. A strong shoulder near 975 $\mathrm{cm}^{-1}$, attributed to the $\mathrm{Mo} \equiv \mathrm{N}$ stretching mode, ${ }^{1,11-13,19,30}$ proves this complex to be the mono-organoimido substituted derivative. Finally, Figure 1 shows the UV-vis absorption spectrum of $\left(n-\mathrm{Bu}_{4} \mathrm{~N}\right)_{2}[1] \cdot 1 / 2 \mathrm{Me}_{2} \mathrm{CO}$ in acetonitrile (a) and, for the sake of comparison, the spectrum of $\left(n-\mathrm{Bu}_{4} \mathrm{~N}\right)_{2}\left[\mathrm{Mo}_{6} \mathrm{O}_{19}\right]$ in the same solvent (b). The lowest-energy electronic transition at $325 \mathrm{~nm}$ in the precursor $\left[\mathrm{Mo}_{6} \mathrm{O}_{19}\right]^{2-}$ has been attributed to a ligand-to-metal charge-transfer transition associated with the terminal oxygen non-bonding $\pi$-type HOMO to the molybdenum $\pi$-type LUMO., ${ }^{78}$ In complex $[1]^{2-}$ the ligand-to-metal charge transfer transition band, observed at $358 \mathrm{~nm}$, exhibits two important features relative to the spectrum of $\left(n-\mathrm{Bu}_{4} \mathrm{~N}\right)_{2}\left[\mathrm{Mo}_{6} \mathrm{O}_{10}\right]$ : (i) its intensity becomes nearly three times, and (ii) its wavelength is bathochromically shifted by $33 \mathrm{~nm}$. These observations indicate that the N-Mo $\pi$-bonding is strongly delocalized through the organic conjugated backbone. ${ }^{7,13,18}$ The spectrum of $\left(n-\mathrm{Bu}_{4} \mathrm{~N}\right)_{2}[1] \cdot 1 / 2 \mathrm{Me}_{2} \mathrm{CO}$ registered in DMSO does not exhibits hipso- or bathochromic effects.

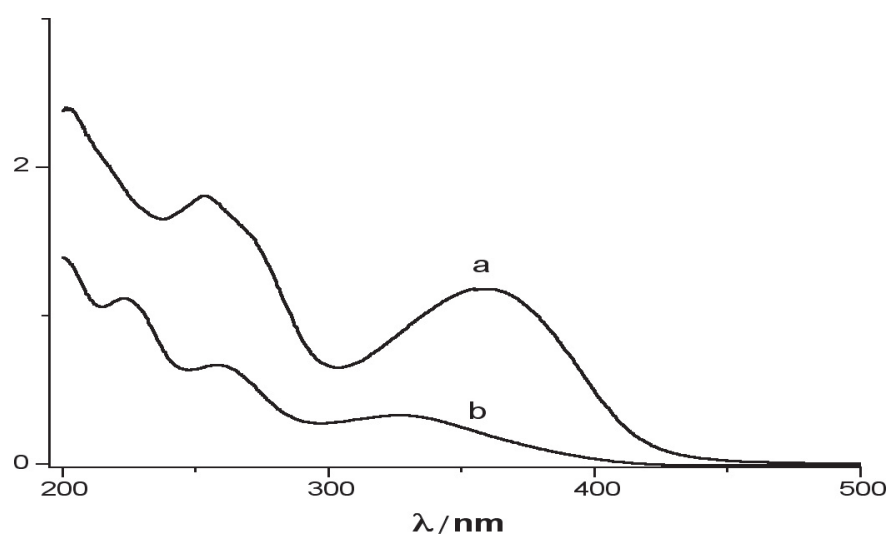

Figure 1. UV-vis absorption spectra of $\left(n-\mathrm{Bu}_{4} \mathrm{~N}\right)_{2}[1] \cdot \frac{1}{2} \mathrm{Me}_{2} \mathrm{CO}$ (a) and $(n$ $\left.\mathrm{Bu}_{4} \mathrm{~N}\right)_{2}\left[\mathrm{Mo}_{6} \mathrm{O}_{19}\right](\mathrm{b})$, in acetonitrile.

\section{Crystal structure}

A summary of $\mathrm{X}$-ray crystal data for $\left(n-\mathrm{Bu}_{4} \mathrm{~N}\right)_{2}[1] \cdot 1 / 2 \mathrm{Me}_{2} \mathrm{CO}$ is presented in Table 1 . Table 2 contains selected bond lengths and angles. The cluster crystallizes in the triclinic space group P-1. The asymmetric unit contains two conformational isomers $\mathrm{A}$ and $\mathrm{B}$, generated by a different orientation of the phenyl ring (see Figure 2). From the structural point of view, both crystallographically independent isomers differ by the rotation of the phenyl ring by $12.1(2)^{\circ}$ relative to the plane including the $\mathrm{Mo}(1)-\mathrm{O}(2)-\mathrm{Mo}(2)-\mathrm{O}(15)-$ $\mathrm{Mo}(6)-\mathrm{O}(17)-\mathrm{Mo}(4)-\mathrm{O}(4)$ atoms in the case of the isomer $\mathrm{A}$, and by $34.5(2)^{\circ}$ relative to the plane including the $\mathrm{Mo}(7)-\mathrm{O}(21)-\mathrm{Mo}(9)-\mathrm{O}(34)-\mathrm{Mo}(12)-\mathrm{O}(32)$ $\mathrm{Mo}(11)-\mathrm{O}(19)$ atoms in the case of the isomer B (see Figure 3). Similar examples have been described for the isoelectronic imido-hexamolybdate clusters $\left[\mathrm{Mo}_{6} \mathrm{O}_{18}\left(\mathrm{NC}_{6} \mathrm{H}_{2}-2,6-\mathrm{Me}_{2}-4-\mathrm{I}\right)\right]^{2-}$ and $\left[\mathrm{MoO}_{6} \mathrm{O}_{18}\left(\mathrm{NC}_{6} \mathrm{H}_{2}-2,6-\mathrm{Me}_{2}-4-\right.\right.$ $\mathrm{C} \equiv \mathrm{CH})]^{2-7}$. Although the majority of the molecular parameters of structures $\mathrm{A}$ and $\mathrm{B}$ are nearly the same, both structures differ in the angles Mo(1)$\mathrm{N}(1)-\mathrm{C}(1)$ and $\mathrm{Mo}(7)-\mathrm{N}(2)-\mathrm{C}(9)$ by $3.4^{\circ}$. These values, near to $180^{\circ}$, and the short Mo-N bond distances of $1.720(6)$ and 1.723(6) $\AA$ for the anions A and $\mathrm{B}$, respectively, are in good accord with the presence of a triple bond in the $\mathrm{Mo} \equiv \mathrm{N}$ fragment. ${ }^{31}$ On the other hand, the $\mathrm{C}-\mathrm{Br}$ bond lengths of isomer $\mathrm{A}$ and $\mathrm{B}$, $1.889(10)$ and 1.888(9) $\AA$, respectively, are similar to the average bond length, $1.897 \AA$, calculated in aromatic bromine compounds. As distinguished from $\left[\mathrm{Mo}_{6} \mathrm{O}_{18}\left(\mathrm{NC}_{6} \mathrm{H}_{4}-4-\mathrm{Br}\right]^{2-},{ }^{18}\right.$ complex $[\mathbf{1}]^{2-}$ does not exhibits dimerization.

Table 1. Crystal data and structure refinement for $\left(n-\mathrm{Bu}_{4} \mathrm{~N}\right)_{2}[1] \cdot \frac{1}{2} \mathrm{Me}_{2} \mathrm{CO}$

\begin{tabular}{|l|l|}
\hline Empirical formula & $\mathrm{C}_{83} \mathrm{H}_{166} \mathrm{Br}_{2} \mathrm{Mo}_{12} \mathrm{~N}_{6} \mathrm{O}_{37}$ \\
Formula weight & 3151.32 \\
Temperature & $298(2) \mathrm{K}$ \\
Wavelength & $0.71073 \AA$ \\
Crystal system & Triclinic \\
Space group & $\mathrm{P}-1$ \\
$a(\AA)$ & $12.5861(15)$ \\
& \\
$b(\AA)$ & $19.083(2)$ \\
$c(\AA)$ & $25.456(3)$ \\
$\alpha\left(^{\circ}\right)$ & $103.313(2)$ \\
$\beta\left(^{\circ}\right)$ & $91.074(2)$ \\
$\gamma\left({ }^{\circ}\right)$ & $99.735(2)$ \\
& $5853.5(12)$ \\
Volume $\left(\AA^{3}\right)$ & 2 \\
$Z$ & 1.995 \\
Absorption coefficient $\left.(\mathrm{mm})^{-1}\right)$ & $0.369 \times 0.238 \times 0.184$ \\
Crystal size (mm $\left.{ }^{3}\right)$ & 1.64 to $28.11^{\circ}$. \\
$\theta$ range for data collection & $-16<=\mathrm{h}<=15$, \\
Index ranges & $-24<=\mathrm{k}<=24$, \\
& $-33<=1<=32$ \\
Reflections collected & 49891 \\
Independent reflections $\left[R_{\text {int }}\right]$ & $25467[0.0564]$ \\
Completeness to $\theta=28.11^{\circ}$ & $89.2 \%$ \\
Absorption correction & None \\
Refinement method & Full-matrix least-squares \\
Data / restraints / parameters & on $F^{2}$ \\
Goodness-of-fit on $F^{2}$ & $25467 / 0 / 1283$ \\
Final $R$ indices $[I>2 \sigma(I)]$ & 0.930 \\
$R$ indices (all data) & $R_{1}=0.0614, w R_{2}=0.1214$ \\
Largest difference & $R_{1}=0.1425, w R_{2}=0.1513$ \\
in peak and hole $\left(\mathrm{e} . \AA^{-3}\right)$ & 1.058 and -0.812 \\
\hline & \\
\hline
\end{tabular}


Table 2. Selected bond lengths $(\AA)$ and angles $\left({ }^{\circ}\right)$ for the two crystallographically independent anions $\mathrm{A}$ and $\mathrm{B}$ observed in complex ( $n$ $\left.\mathrm{Bu}_{4} \mathrm{~N}\right)_{2}[1] \cdot 1 / 2 \mathrm{Me}_{2} \mathrm{CO}$.

\begin{tabular}{|l|l|l|l|}
\hline Anion A & & Anion B & \\
Bond lengths & & Bond lengths & \\
$\mathrm{Mo}(1)-\mathrm{N}(1)$ & $1.720(6)$ & $\mathrm{Mo}(7)-\mathrm{N}(2)$ & $1.723(6)$ \\
$\mathrm{Mo}(1)-\mathrm{O}_{\mathrm{b}}(1)$ & $1.959(5)$ & $\mathrm{Mo}(7)-\mathrm{O}_{\mathrm{b}}(19)$ & $1.934(5)$ \\
$\mathrm{Mo}(1)-\mathrm{O}_{\mathrm{b}}(2)$ & $1.924(5)$ & $\mathrm{Mo}(7)-\mathrm{O}_{\mathrm{b}}(20)$ & $1.944(5)$ \\
$\mathrm{Mo}(1)-\mathrm{O}_{\mathrm{b}}(3)$ & $1.945(5)$ & $\mathrm{Mo}(7)-\mathrm{O}_{\mathrm{b}}(21)$ & $1.958(5)$ \\
$\mathrm{Mo}(1)-\mathrm{O}_{\mathrm{b}}(4)$ & $1.959(5)$ & $\mathrm{Mo}(7)-\mathrm{O}_{\mathrm{b}}(22)$ & $1.951(5)$ \\
$\mathrm{Mo}(1)-\mathrm{O}_{\mathrm{c}}(13)$ & $2.209(4)$ & $\mathrm{Mo}(7)-\mathrm{O}_{\mathrm{c}}(31)$ & $2.206(4)$ \\
$\mathrm{Mo}(6)-\mathrm{O}_{\mathrm{c}}(13)$ & $2.364(4$ & $\mathrm{Mo}(12)-\mathrm{O}_{\mathrm{c}}(31)$ & $2.341(4)$ \\
$\mathrm{Mo}(6)-\mathrm{O}_{\mathrm{t}}(18)$ & $1.669(5)$ & $\mathrm{Mo}(12)-\mathrm{O}_{\mathrm{t}}(36)$ & $1.675(5)$ \\
$\mathrm{Mo}(6)-\mathrm{O}_{\mathrm{b}}(14-17)$ & $1.915^{\mathrm{a}}$ & $\mathrm{Mo}(12)-\mathrm{O}_{\mathrm{b}}(32-35)$ & $1.908^{\mathrm{a}}$ \\
$\mathrm{Mo}(2-6)-\mathrm{O}_{c}(13)$ & $2.330^{\mathrm{a}}$ & $\mathrm{Mo}(8-11)-\mathrm{O}_{c}(31)$ & $2.330^{\mathrm{a}}$ \\
$\mathrm{Mo}(2-5)-\mathrm{O}_{\mathrm{t}}$ & $1.670^{\mathrm{a}}$ & $\mathrm{Mo}(8-11)-\mathrm{O}_{\mathrm{t}}$ & $1.670^{\mathrm{a}}$ \\
$\mathrm{Mo}(2)-\mathrm{O}_{\mathrm{b}}$ & $1.919^{\mathrm{a}}$ & $\mathrm{Mo}(8)-\mathrm{O}_{\mathrm{b}}$ & $1.920^{\mathrm{a}}$ \\
$\mathrm{Mo}(3)-\mathrm{O}_{\mathrm{b}}$ & $1.912^{\mathrm{a}}$ & $\mathrm{Mo}(9)-\mathrm{O}_{\mathrm{b}}$ & $1.914^{\mathrm{a}}$ \\
$\mathrm{Mo}(4)-\mathrm{O}_{\mathrm{b}}$ & $1.921^{\mathrm{a}}$ & $\mathrm{Mo}(10)-\mathrm{O}_{\mathrm{b}}$ & $1.918^{\mathrm{a}}$ \\
$\mathrm{Mo}(5)-\mathrm{O}_{\mathrm{b}}$ & $1.910^{\mathrm{a}}$ & $\mathrm{Mo}(11)-\mathrm{O}_{\mathrm{b}}$ & $1.915^{\mathrm{a}}$ \\
$\mathrm{N}(1)-\mathrm{C}(1)$ & $1.384(8)$ & $\mathrm{N}(2)-\mathrm{C}(9)$ & $1.387(9)$ \\
$\mathrm{C}(4)-\mathrm{Br}(1)$ & $1.889(10)$ & $\mathrm{C}(12)-\mathrm{Br}(2)$ & $1.888(9)$ \\
& & & \\
$\mathrm{Bond}$ angles & & $\mathrm{Bond}$ angles & \\
$\mathrm{N}(1)-\mathrm{Mo}(1)-\mathrm{O}(1-4)$ & $101.9^{\mathrm{a}}$ & $\mathrm{N}(2)-\mathrm{Mo}(7)-\mathrm{O}(19-22)$ & $101.7^{\mathrm{a}}$ \\
$\mathrm{Mo}(1)-\mathrm{N}(1)-\mathrm{C}(1)$ & $172.2(6)$ & $\mathrm{Mo}(7)-\mathrm{N}(2)-\mathrm{C}(9)$ & $175.6(6)$ \\
$\mathrm{N}(1)-\mathrm{C}(1)-\mathrm{C}(2)$ & $117.4(8)$ & $\mathrm{N}(2)-\mathrm{C}(9)-\mathrm{C}(10)$ & $119.0(8)$ \\
$\mathrm{N}(1)-\mathrm{C}(1)-\mathrm{C}(6)$ & $120.8(8)$ & $\mathrm{N}(2)-\mathrm{C}(9)-\mathrm{C}(14)$ & $119.3(7)$ \\
& & & \\
& & & \\
\hline
\end{tabular}

$\mathrm{t}=$ terminal $; \mathrm{b}=$ bridge $; \mathrm{c}=$ central $; \mathrm{a}=$ average

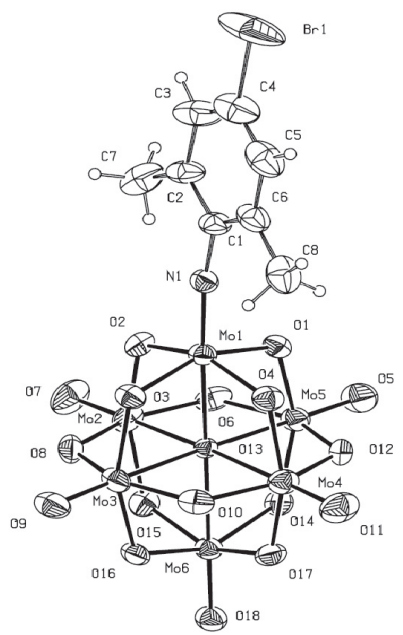

A

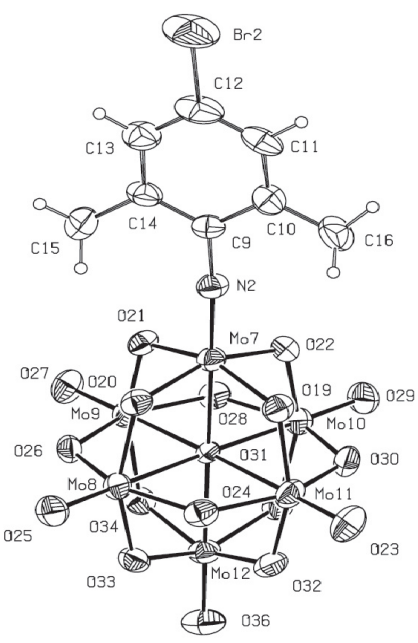

B
Figure 2. ORTEP drawings with the atom numbering scheme for the conformational isomers A and B of $[\mathbf{1}]^{2-}$. Displacement ellipsoids are at $50 \%$ probability level.

Finally, as it has been observed in arylimido-derivatives of hexamolybdate, when the arylimido group substitutes an oxygen atom of the $\left[\mathrm{Mo}_{6} \mathrm{O}_{19}\right]^{2-}$ precursor the bond lengths of Mo- $\mathrm{O}_{t}$ do not change significantly, however, the $\mathrm{Mo}(1)-\mathrm{O}_{b}$ are lengthened and that of $\mathrm{Mo}(1)-\mathrm{O}^{22}$ is shortened. On the other hand, the $\mathrm{Mo}(1)-\mathrm{O}_{\mathrm{c}}$ is always shorter than that of $\mathrm{Mo}(6)-\mathrm{O}_{\mathrm{c}}$. In the case of complex $\left(n-\mathrm{Bu}_{4} \mathrm{~N}\right)_{2}[\mathbf{1}] \cdot 1 / 2 \mathrm{Me}_{2} \mathrm{CO}$, the $\mathrm{Mo}(1)-\mathrm{O}(13)$ bond length, in the conformational isomer $\mathrm{A}$, is shorter than that of $\mathrm{Mo}(6)-\mathrm{O}(13)$ by 0.155 , while in the conformational isomer B this difference is 0.135 (see Tables 2). Table 3 compares the structural features of arylimido-derivatives of hexamolybdate. The influence of the substituent groups on the phenyl rings seems to be weak, so that a meaningful structural correlation between the bond lengths and the Hammett constants, $\sigma_{p}-\mathrm{X}$, could not be established.

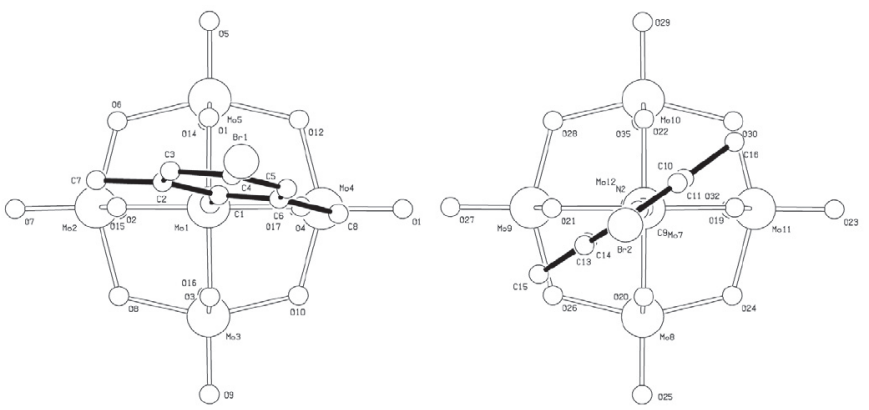

Figure 3. Spatial rotation of the phenyl rings in the structural isomers $A$ and B of complex $[1]^{2-*} \mathrm{~A}, 12.1(2)^{\circ} ; \mathrm{B}, 34.5(2)^{\circ}$.

\section{Electrochemistry}

In DMF solution, Cyclic Voltammetry of $\left(n-\mathrm{Bu}_{4} \mathrm{~N}\right)_{2}[\mathbf{1}] \cdot 1 / 2 \mathrm{Me}_{2} \mathrm{CO}$ exhibits two irreversible one-electron reduction processes at $E p=-0.785$ and -0.890 $\mathrm{V}(v s \mathrm{Ag} / \mathrm{AgCl})$. Corresponding values for $\left[\mathrm{Mo}_{6} \mathrm{O}_{18}\left(\mathrm{NC}_{6} \mathrm{H}_{4}-4-\mathrm{Me}\right)\right]^{2-}$ are -0.52 and $-1.09 \mathrm{~V}$, whereas for the $\left[\mathrm{Mo}_{6} \mathrm{O}_{10}\right]^{2-}$ are -0.39 and $-1.12 \mathrm{~V} .{ }^{1}$ The first process can be attributed to the reduction of the hexamolybdate fragment of the $[\mathbf{1}]^{2-}$ complex to afford the reduced anionic species $[\mathbf{1}]^{3-}$. This potential is more negative than those of $\left[\mathrm{Mo}_{6} \mathrm{O}_{18}\left(\mathrm{NC}_{6} \mathrm{H}_{4}-4-\mathrm{Me}\right)\right]^{2-}$ and $\left[\mathrm{Mo}_{6} \mathrm{O}_{19}\right]^{2-}$ which indicates that the electron-accepting ability of the bromo group has been compensated by the two methyl groups. Under the same experimental conditions, ferrocene exhibits a reversible process at $E^{1 / 2}=+0.566 \mathrm{~V}(\Delta E=68 \mathrm{mV})$.

Table 3. Comparison of selected bond lengths $(\AA)$ and angles $\left({ }^{\circ}\right)$ of arylimido-hexamolybdates, $\left[\mathrm{Mo}_{6} \mathrm{O}_{18}(\mathrm{NR})\right]^{2-}$.

\begin{tabular}{|c|c|c|c|c|c|c|c|c|}
\hline$R=$ & Mo(1)-N & $\mathrm{Mo}_{0}(1)-Q_{0}^{\mathrm{s}}$ & $M_{0}(1)-Q_{c}$ & $M_{0}(6)-Q_{\varepsilon}$ & $M_{0}(6)-Q_{t}$ & $\mathrm{Mo}_{0}(1)-\mathrm{N}-\mathrm{C}$ & $\mathrm{C}-\mathrm{X}$ & Ref. \\
\hline$-\mathrm{C}_{6} \mathrm{H}_{4} 4-\mathrm{Cl}$ & $1.686(3)$ & 1.927 & $2237(1)$ & $2.340(1)$ & $1.685(4)$ & $1636(6)$ & 1.656 & 12 \\
\hline$-\mathrm{C}_{5} \mathrm{H}_{4} 4-\mathrm{Br}$ & $1.698(13)$ & 1.934 & $2.234(8)$ & $2.347(8)$ & $1.659(10)$ & $163.6(14)$ & 1.854 & 18 \\
\hline$-\mathrm{C}_{6} \mathrm{H}_{3}-2.6-\mathrm{Me}_{2}$ & $1.723(7)$ & 1.953 & $2.230(6)$ & $2.337(6)$ & $1.697($ () & $178.4(7)$ & & 7 \\
\hline \multirow[t]{2}{*}{$-\mathrm{C}_{6} \mathrm{H}_{2}-2,6-\mathrm{Me}_{2} 4-\mathrm{Br}^{*}$} & $1.720(6)$ & 1.946 & $2.209(4)$ & $2.364(4)$ & $1.669(5)$ & $172.2(6)$ & $1.889(10)^{*}$ & This work \\
\hline & $1.723(6)$ & 1.946 & $2.206(4)$ & $2.341(4)$ & $1.675(5)$ & $175.6(6)$ & $1.888(9) *$ & This work \\
\hline \multirow[t]{2}{*}{$-\mathrm{C}_{6} \mathrm{H}_{2}-2,6-\mathrm{Me}_{2} 4-\mathrm{I}^{*}$} & $1.733(6)$ & 1.947 & $2222(4)$ & $2.349(4)$ & $1.690(5)$ & $1728(6)$ & 2.093 & 7 \\
\hline & $1.738(6)$ & 1.936 & $2.249(4)$ & $2.374(4)$ & $1.702(5)$ & $165.9(6)$ & 2.086 & 7 \\
\hline \multirow{2}{*}{$-\mathrm{C}_{6} \mathrm{H}_{2}-2,6-\mathrm{Mc}_{2} 4-\mathrm{C}=\mathrm{CH}^{*}$} & $1.729(5)$ & 1.943 & $2.232(4)$ & $2.353(4)$ & $1.682(4)$ & $172.8(6)$ & & 7 \\
\hline & $1.727(5)$ & 1.950 & $2.210(3)$ & $2.342(3)$ & $1.686(4)$ & $165.9(6)$ & & 7 \\
\hline$-\mathrm{C}_{6} \mathrm{H}_{2}-2,-6-\mathrm{Me}_{2} 4 \mathrm{C}=\mathrm{C}=\mathrm{C}-\mathrm{Tol}-p$ & $1.739(19)$ & 1.936 & 2.193(14) & $2.334(14)$ & $1.68(2)$ & $171.4(18)$ & & 8 \\
\hline$-\mathrm{C}_{5} \mathrm{H}_{4} 4-\mathrm{CH}=\mathrm{CH}_{2}$ & $1.728(7)$ & 1.944 & $2223(5)$ & $2.353(5)$ & $1.689(6)$ & $1599(7)$ & & 5 \\
\hline$-\mathrm{C}_{5} \mathrm{H}_{4} 4-\mathrm{Me}_{0}$ & $1.661(18)$ & 1.960 & $2.202(11)$ & $2.344(9)$ & n. $\mathrm{r}$. & $154.2(16)$ & & 1 \\
\hline$-\mathrm{C}_{6} \mathrm{H}_{4}-2-\mathrm{Me}$ & $1.772(3)$ & 1.933 & $2.205(1)$ & $2.349(1)$ & $1.700(2)$ & $173.9(16)$ & & 12 \\
\hline$-\mathrm{C}_{6} \mathrm{H}_{3}-2,2,-\mathrm{Pr}_{\mathrm{r}_{3}}$ & $1.739(15)$ & 1.954 & $2.254(10)$ & $2.312(10)$ & $1.649(14)$ & $176.3(15)$ & & 6 \\
\hline$-\mathrm{C}_{6} \mathrm{H}_{4} 4-\mathrm{OMC}$ & $1.733(4)$ & 1.945 & $2.213(3)$ & $2.355(3)$ & $1.671(3)$ & $163.3(4)$ & & 11 \\
\hline$-\mathrm{C}_{6} \mathrm{H}_{4} 4-\mathrm{NMe}_{2}$ & $1.730(4)$ & 1.946 & $2220(2)$ & $2.354(3)$ & $1.675(3)$ & $160.3(4)$ & & 19 \\
\hline$-\mathrm{C}_{6} \mathrm{H}_{2}-2,6-\mathrm{Me}_{3} 4-\mathrm{C} \equiv \mathrm{C}-\left(\eta^{3}-\right.$ & $1.731(8)$ & 1.953 & $2.205(5)$ & $2.356(5)$ & $1.676(6)$ & $178.5(6)$ & & 13 \\
\hline $\left.\mathrm{C}_{5} \mathrm{I}_{4} \mathrm{H}_{4}\right) \mathrm{F}_{0}\left(\eta^{5}-\mathrm{CP}_{\mathrm{p}}\right)$ & & & & & & & & \\
\hline
\end{tabular}

*The asymmetric unit contains two crystallographically independent anions; aaverage; bbridge; 'central; 'terminal in trans-position; $\mathrm{n} . \mathrm{r} .=$ not reported; $\mathrm{X}=\mathrm{Cl}, \mathrm{Br}$, I; *average bond length for organic molecules $=1.897 \AA$.

\section{CONCLUDING REMARKS}

We have successfully prepared and characterized by spectroscopic methods and by X-ray diffraction analysis the new functionalized Lindqvisttype hexamolybdate cluster containing an arylimido moiety bearing two methyl substituent groups in the 2,6-positions and an electron-withdrawing bromo group in the remote 4-position of the phenyl group, $\left(n-\mathrm{Bu}_{4} \mathrm{~N}\right)_{2}\left[\mathrm{Mo}_{6} \mathrm{O}_{18}\left(\mathrm{NC}_{6} \mathrm{H}_{2}-\right.\right.$ $\left.\left.2,6-\mathrm{Me}_{2}-4-\mathrm{Br}\right)\right]$. From the synthetic point of view, the C-Br moiety of this new precursor may be useful as an additional reaction site in this type of cluster for a further functionalization through a carbon-carbon coupling reaction,,$^{8-10,13}$ and, 
potentially, with nucleophilic species to afford new molecular or polymeric hybrid materials.

From the structural point of view, both conformational isomers $\mathrm{A}$ and $\mathrm{B}$ observed in the asymmetric unit of $\left(n-\mathrm{Bu}_{4} \mathrm{~N}\right)_{2}[1] \cdot 1 / 2 \mathrm{Me}_{2} \mathrm{CO}$ differ only by (i) the different rotation of the phenyl rings relative to the hexamolybdate skeleton, and (ii) the angles $\mathrm{Mo}(1)-\mathrm{N}(1)-\mathrm{C}(1)=172.2(6)$ and $\mathrm{Mo}(7)-\mathrm{N}(2)-\mathrm{C}(9)=175.6(6)$, which prove the presence of a $\mathrm{Mo} \equiv \mathrm{N}$ triple bond.

\section{Supplementary materials}

Crystallographic data (excluding structure factors) for the structure reported in this paper, $\left(n-\mathrm{Bu}_{4} \mathrm{~N}\right)_{2}[\mathbf{1}] \cdot 1 / 2 \mathrm{Me}_{2} \mathrm{CO}$, have been deposited with the Cambridge Crystallographic Data Centre as supplementary publication no. CCDC-631809. Copies of the data can be obtained free of charge on application to CCDC, 12 Union Road, Cambridge CB2 1EZ, UK (fax: (+44)1223-336-033; e-mail: deposit@ccdc.cam.ac.uk).

\section{ACKNOWLEDGEMENTS}

Financial support from the Fondo Nacional de Desarrollo Científico y Tecnológico, FONDECYT, Chile, grant no. 1060490 (D. C. and C. M.) and the Pontificia Universidad Católica de Valparaíso, are gratefully acknowledged.

\section{REFERENCES}

1. Y. Du, A. L. Rheingold, E. A. Maatta, J. Am. Chem. Soc. 114, 345 (1992).

2. B. J. B. Strong, R. Ostrander, A. L. Rheingold, E. A Maatta, J. Am. Chem. Soc. 116, 3601(1994).

3. W. Clegg, R. J. Errington, K. A. Fraser, S. A. Holmes, A. Schäfer, J. Chem. Soc., Chem. Commun. 455 (1995).

4. J. L. Stark, V. G. Young, E. A. Maatta, Angew. Chem. Int. Ed. Engl. 34, 2547 (1995).

5. A. R. Moore, H. Kwen, A. M. Beatty, E. A. Maatta, Chem. Commun. 1793 (2000).

6. J. B. Strong, G. P. A. Yap, R. Ostrander, L. M. Liable-Sands, A. L. Rheingold, R. Thouvenot, P. Gouzerh, E. A. Maatta, J. Am. Chem. Soc. 122, 639 (2000).

7. Y. Wei, B. Xu, C. L. Barnes, Z. Peng, J. Am. Chem. Soc. 123, 4083 (2001).

8. B. Xu, Y. Wei, C. L. Barnes, Z. Peng, Angew. Chem. Int. Ed. 40, 2290 (2001).
9. L. Xu, M. Lu, B. Xu, Y. Wei, Z. Peng, D. R. Powell, Angew. Chem. Int. Ed. 41, 4129 (2002).

10. M. Lu, Y. Wei, B. Xu, C. F. Cheung, Z. Peng, D. R. Powell, Angew. Chem. Int. Ed. 41, 1566 (2002).

11. R. A. Roesner, S. C. McGrath, J. T. Brockman, J. D. Moll, D. X. West, J. K. Swearingen, A. Castineiras, Inorg. Chim. Acta 342, 37 (2003).

12. P. Wu, Q. Li, N. Ge, Y. Wei, Y. Wang, P. Wang, H. Guo, Eur. J. Inorg. Chem. 2819 (2004)

13. J. Kang, J. A. Nelson, M. Lu, B. Xie, Z. Peng, D. R. Powell, Inorg. Chem. 43, 6408 (2004).

14. M. Lu, J. Kang, D. Wang, Z. Peng, Inorg. Chem. 44, 7711 (2005).

15. M. Lu, B. Xie, J. Kang, F-C. Chen, Y. Yang, Z. Peng, Chem. Mater. 17, $402(2005)$.

16. Y. Xia, Y. Wei, Y. Wang, H. Guo, Inorg. Chem. 44, 9823 (2005).

17. I. Bar-Nahum, K. V. Narasimhulu, L. Weiner, R. Neumann, Inorg. Chem. 44, 4900 (2005).

18. Q. Li, P. Wu, Y. Xia, Y. Wei, H. Guo, J. Organomet. Chem. 691, 1223 (2006).

19. Z. Xiao, Y. Zhu, Y. Wei, Y. Wang, Inorg. Chem. Commun. 9, 400 (2006).

20. T. R. Mohs, G. P. A. Yap, A. L. Rheingold, E. A. Maatta, Inorg. Chem. $\mathbf{3 4}$ 9 (1995).

21. Y. Wei, M. Lu, C F. Cheung, C. L. Barnes, Z. Peng, Inorg. Chem. 40, 5489 (2001).

22. L. Yan, Z.-M. Su, W. Guan, M. Zhang, G.-H. Chen, L. Xu, E.-B. Wang, J. Phys. Chem. 108 B, 17337 (2004).

23. L. Yan, G. Yang, W. Guan, Z. Su, R. Wang, J. Phys. Chem. 109 B, 22332 (2005).

24. D. Mac-Leod Carey, A. Muñoz-Castro, C. J. Bustos, J. M. Manríquez, R. Arratia-Pérez, J. Phys. Chem., 111 B, 6563 (2007).

25. (a) Polyoxometalates, Chem. Rev. 98, 3-387(1998). (b) P. Gouzerh, A. Proust, Chem. Rev. 98, 77 (1998).

26. N. Hur, W. G. Klemperer, R.-C. Wang, Inorg. Synth. 27, 78-79 (1990).

27. SAINT-PLUS (version 6.02), Bruker Analytical X-ray Systems Inc., Madison, WI, USA (1999)

28. G. M. Sheldrick, SADABS (Version 2.05): Empirical Absorption Program University of Göttingen, Germany.

29. SHELXTL, Reference Manual (Version 6.14). Bruker Analytical X-Ray Systems Inc., Madison, WI, USA (1998).

30. A. Proust, R. Thouvenot, M. Chaussade, F. Robert, P. Gouzerh, Inorg. Chim. Acta 123 (2001) 4083.

31. D. E. Wigley, Prog. Inorg. Chem. 42 (1994) 239. 